\title{
HUBUNGAN PENGETAHUAN DENGAN MINAT IBU BALITA TENTANG TAMAN POSYANDU DI KELURAHAN COKROMENGGALAN KECAMATAN PONOROGO KABUPATEN PONOROGO.
}

(The correlation knowledge of mother of toddler with interest to the mother of toddler about Taman Posyandu in Posyandu Pos 3 Cokromenggalan, Cokromenggalan Village, Ponorogo

District, Ponorogo Regency)

Sumini $^{1)}$, Arifatul Rosyidah ${ }^{2)}$

Akbid Harapan Mulya Ponorogo

\begin{abstract}
Taman Posyandu is development of posyandu purnama or independent which give additional service to develop early childhood and bina keluarga balita. Total data of toddler in posyandu pos 3 Cokromenggalan Village has 52 people. At 2016, in posyandu pos 3 Cokromenggalan Village has 22 toddler that followed Taman Posyandu. Based on study of preliminary studies there are 6 from 10 mother of toddler is lack of knowledge about Taman Posyandu. The purpose of research is to know The connection knowledge mother of toddler with interest to the mother of toddler about Taman Posyandu in posyandu pos 3 Cokromenggalan, Cokromenggalan Village, Ponorogo District, Ponorogo Regency.

This type of research is quantitative. The research design used Cross Sectional and this research was conducted at Posyandu Pos 3 Cokromenggalan in January 2017. The population is all the mothers of toddler with the number of 52, the number of samples 30, with the technique of Accidental Sampling. Independent variables (knowledge) and dependent variables (interests). Instrument with questionnaire, and Spearman Rank statistical test at 0.05 significance level.

Based on research result of knowledge about taman posyandu half of 15 respondents $(50 \%)$ with less knowledge. Interest in following the taman posyandu almost half of 16 respondents (53.3\%) with negative interest. The result of statistic test by using Spearman Rank shows that $\rho=0,000$ with correlation coefficient value 0.803, $\rho$ which can be $<0.05$ so that $\mathrm{HO}$ is rejected which means there is the correlations knowledge of mother toddler with interest to the mother of toddler about taman posyandu in posyandu post 3 Cokromenggalan,Cokromenggalan village, Ponorogo district, Ponorogo regency with a level flatness is very strong.

The conclusion is that mother have low knowledge about Taman Posyandu can cause the interest mother about Taman Posyandu is low. It is recommended that local health personnel to improve the extension of the importance of the visit to the Taman Posyandu to toddler and useful for enhance mother of knowledge about the importance of monitoring, detecting growth for children, providing health services and stimulation of education early.
\end{abstract}

Keyword: Knowledge, Interest, Taman Posyandu, Mother of toddler

\section{PENDAHULUAN}

Pos Pelayanan Terpadu (Posyandu) adalah kegiatan kesehatan dasar yang diselenggarakan dari, oleh dan untuk masyarakat yang dibantu oleh petugas kesehatan di suatu wilayah kerja puskesmas, dimana program ini dapat dilaksanakan di balai dusun, balai kelurahan, maupun tempattempat lain yang mudah didatangi oleh masyarakat (Ismawati, 2010: 3).
Taman posyandu merupakan pengembangan dari posyandu. Taman Posyandu dibentuk untuk ibu-ibu balita antara lain supaya mereka mengetahui peran dan tugas seorang ibu. Mereka juga punya kesanggupan untuk memecahkan persoalan-persoalan sederhana yang berhubungan dengan anak. Tidak lupa, materi kegiatan dapat membantu ibu-ibu balita selalu memberikan pengasuhan dan 
pendidikan terbaik buat anak-anaknya (Dinkes Jatim, 2013)

Kehadiran Taman Posyandu bertujuan untuk melejitkan semua potensi yang dimiliki anak. Kecepatan perkembangan setiap anak berbeda, sehingga kegiatan harus diarahkan untuk memenuhi kebutuhan masing-masing anak sesuai dengan tahap perkembangannya. Taman Posyandu tidak untuk melatih atau memaksa anak dengan kemampuan tertentu yang tidak sesuai dengan tahap perkembangan anak, sekedar untuk memenuhi keinginan orangtua. Hal ini akan merugikan perkembangan anak itu sendiri. Untuk mencapai sebuah kompetensi anak, sebaiknya dilakukan melalui kegiatan bermain dengan menggunakan berbagai metode dan teknik yang sesuai dengan prinsip-prinsip pendidikan (Ardhiansam, 2013).

Jumlah Pos Pelayanan Terpadu (Posyandu) di Jawa Timur tahun 2010 sampai dengan tahun 2014 menunjukkan kenaikan, akan tetapi tidak menunjukkan perubahan yang signifikan. Pada akhir tahun 2014 jumlah balita sebanyak 3.009.546 jiwa, sedangkan jumlah Posyandu yang ada sebanyak 46.179 pos. Jadi rasio jumlah Posyandu dengan jumlah balita adalah 1:67. Jika dibandingkan dengan standar Posyandu, untuk 1 Posyandu melayani 68 Balita, berarti angka tersebut sudah memenuhi standar yang ditetapkan. Sehingga jumlah Posyandu di Jawa Timur untuk tahun-tahun mendatang dimungkinkan tidak terjadi lonjakan yang besar. Secara kualitas, berdasarkan tingkat perkembangan Posyandu PURI (Purnama-Mandiri) dari tahun ke tahun menunjukkan peningkatan khususnya dalam lima tahun terakhir mulai dari 50,29 \%; 54,07 \%; 60,28 \%; 62,37\%; dan $66,12 \%$ pada tahun 2014, sehingga terdapat kenaikan 3,75 \% dari tahun 2013 ke 2014. Dan di tahun 2013 dilanjutkan tahun 2014 dan 2015 di Jawa Timur diupayakan dibentuknya sekitar 10.000 taman posyandu (Profil Dinas Kesehatan Jawa Timur, 2014).

Data dari Dinas Kesehatan Kabupaten Ponorogo menunjukkan, sebanyak 36.972 $(78,4 \%)$ anak balita di Kabupaten Ponorogo, Jawa Timur, yang mendapatkan pelayanan kesehatan. Jumlah Posyandu di Kabupaten
Ponorogo saat ini adalah 1.122 unit dengan rincian : Posyandu Purnama mencapai 70,14\%, Posyandu Mandiri mencapai 2,32\%, dan Posyandu Aktif mencapai $72,46 \%$. Sedangkan jumlah Taman Posyandu di Kabupaten Ponorogo sebanyak 26 unit. (Profil Dinas Kesehatan Ponorogo, 2014).

Hasil studi pendahuluan di Kelurahan Cokromenggalan Kecamatan Ponorogo Kabupaten Ponorogo yang dilakukan tanggal 19 November 2016, didapatkan data jumlah posyandu di Kelurahan Cokromenggalan Kecamatan Ponorogo Kabupaten Ponorogo sebanyak 5 Posyandu dengan jumlah balita 264 balita terdiri dari 141 balita laki-laki dan 132 balita perempuan. Sedangkan jumlah Taman Posyandu di Kelurahan Cokromenggalan Kecamatan Ponorogo Kabupaten Ponorogo adalah 1 Taman Posyandu dengan jumlah balita sebanyak 52 balit, dan pada 5 bulan terakhir, bulan juli-november hanya didapatkan jumlah ibu balita yang berminat datang ke taman posyandu pos 3 Cokromenggalan melalui daftar hadir sebanyak 30 Ibu (Juli), 26 (Agustus), 31 (September), 27 (Oktober), 22 (November).

Hasil wawancara pada bulan November tahun 2016, dari 10 orang didapatkan 6 orang $(60 \%)$ dengan pengetahuan kurang tentang taman posyandu, 4 orang $(40 \%)$ dengan pengetahuan cukup tentang taman posyandu. Dari 6 orang yang berpengetahuan kurang didapatkan seluruhnya (100\%) dengan minat negatif terhadap taman posyandu. Sehingga dengan pengetahuan yang kurang mempengaruhi minat ibu balita untuk mengikuti kegiatan taman posyandu.

Kurangnya minat ibu tentang taman posyandu dapat berdampak pada kunjungan yang kurang pula dalam mengikuti kegiatan posyandu. Padahal taman posyandu sangat diperlukan karena masa-masa pada rentangan usia 
dini merupakan masa emas. Kesadaran ibu balita hingga saat ini untuk datang ke Taman Posyandu masih sangat kurang sehingga pertumbuhan dan perkembangan buah hatinya menjadi kurang terkontrol. Salah satu manfaat datang ke Taman Posyandu adalah ibu balita dapat memantau berat badan balitanya secara teratur karena perubahan berat badan menggambarkan perubahan konsumsi makanan atau adanya gangguan kesehatan, kedua ibu balita dapat mengenali masalah kesehatan dan gizi anggotanya, ketiga ibu mampu mengatasi masalah pertumbuhan dan perkembangan balita, baik oleh dirinya sendiri atau dengan bantuan petugas (Ardhiansam, 2013).

Dampak yang terjadi ditempat penelitian di wilayah Posyandu Pos 3 Cokromenggalan dari 6 orang yang mempunyai minat negatif didapatkan tumbuh kembang anak yang tidak sesuai dengan tahapan tumbuh kembang.

Upaya yang bisa dilakukan memberikan penyuluhan kepada ibu balita untuk meningkatkan pengetahuan dan manfaat tentang Taman Posyandu bagi tumbuh kembang balitanya, agar ibu balita berminat untuk datang ke Taman Posyandu. Berdasarkan dari data latar belakang diatas peneliti tertarik untuk meneliti " Hubungan Pengetahuan Ibu Balita Dengan Minat Ibu Balita Tentang Taman Posyandu Di Posyandu Pos 3 Cokromenggalan Kelurahan Cokromenggalan Kecamatan Ponorogo Kabupaten Ponorogo"

\section{TINJAUAN PUSTAKA}

\section{Konsep Pengetahuan}

Pengetahuan adalah hasil dari tahu, dan ini terjadi setelah orang melakukan penginderaan terhadap suatu obyek tertentu. Pengindraan terjadi melalui pancaindra manusia, yakni indra penglihatan, pendengaran, penciuman, rasa dan raba. Sebagian besar pengetahuan manusia diperoleh melalui mata dan telinga. Pengetahuan merupakan unsur yang paling utama dalam membentuk tindakan seseorang (overt behaviour) (Notoatmodjo, 2007: 139).

Menurut penelitian Roger dalam Notoatmodjo (2007: 140) mengungkapkan bahwa di dalam diri seseorang sebelum orang tersebut melakukan hal baru akan terjadi suatu proses yang berurutan, yaitu:

1) Awareness (Kesadaran), dimana orang tersebut memahami objek atau stimulus terlebih dahulu.

2) Interest, dimana seseorang mulai tertarik terhadap stimulus (obyek).

3) Evaluation (mempertimbangkan), mengevaluasi baik dan tidaknya suatu stimulus bagi dirinya.

4) Trial (mencoba), seseorang telah mencoba melakukan hal baru.

5) Adoption (beradaptasi), subyek telah berperilaku baru sesuai dengan pengetahuan, kesadaran dan sikapnya terhadap stimulus.

Faktor-faktor yang mempengaruhi pengetahuan, antara lain:

1. Faktor Internal

a) Pendidikan

Pendidikan diperlukan untuk mendapat informasi misalnya hal-hal yang menunjang kesehatan sehingga dapat meningkatkan kualitas hidup. Menurut YB Mantra yang dikutip Notoatmodjo (2013), pendidik dapat mempengaruh seseorang termasuk juga prilaku seseorang akan pola hidup terutama dalam memotivasi untuk sikap berperan serta dalam pembangun (Nursalam, 2013) pada umumnya makin tinggi pendidikan seseorang makin mudah menerima informasi.

b) Perkerjaan

Menurut Thomas yang dikutip oleh (Nursalam, 2013), perkerjaan adalah keburukan yang harus dilakukan terutama untuk menunjang kehidupannya dan kehidupan keluarga. Perkerjaan bukanlah sumber kesenangan, tetapi lebih banyak merupakan cara mencari nafkah yang membosankan, berulang dan banyak tantangan.Sedangkan berkerja umumnya merupakan kegiatan yang menyita waktu.bagi ibu-ibu yang akan mempunyai pengaruh terhadap kehidupan keluarga.

c) Umur 
Mengemukakan bahwa makin tua umur seseorang maka proses-proses perkembangan mentalnya bertambah baik, akan tetapi pada umur tertentu, bertambah nya proses perkembangan mental ini tidak secepat seperti berumur belasan tahun. Maka dapat simpulkan bahwa bertambahnya umur seseorang dapat berpengaruh pada pertambahan pengetahuan yang di perolehanya, akan tetapi pada umur tertentu atau menjelang usia lanjut kemampuan penerimaan atau mengingat suatu pengetahuan akan berkurang.

2. Faktor Ekternal

a) Lingkungan

Merupakan salah satu faktor yang mempengaruhi pengetahuan seseorang.Lingkungan memberikan pengaruh pertama bagi seseorang, dimana seseorang dapat mempelajari hal-hal yang baik dan juga hal-hal yang buruk tergantung pada sifat kelompoknya.

b) Sosial budaya

Sosial budaya mempunyai pengaruh pada pengetahuan seseorang memperoleh suatu kebudayaan dalam hubungannya dengan orang lain, karena hubungan ini seseorang mengalami suatu proses belajar dan memperoleh suatu pengetahuan (Wawan, 2011:16-18).

\section{Konsep Minat}

Minat adalah rasa suka dan rasa ketertarikan pada suatu hal atau aktifitas tanpa ada yang menyuruh, minat pada hakekatnya adalah penerimaan hubungan antara diri sendiri dengan sesuatu di luar dirinya. Semakin kuat atau semakin dekat hubungan tersebut maka semakin besar minatnya. (Slameto, 2015:180).

Aspek-Aspek atau Kategori Minat :

Dalam Notoatmodjo (2007) ini meliputi lima kategori yaitu:

1) Penerimaan (receiving)

2) Menanggapi (responding)

3) Penilaian (valuting)

4) Organisasi (organization)

5) Pencirian (characterization)

Faktor-faktor yang Mempengaruhi Minat :

1) Umur responden

2) Tingkat pendidikan

3) Jenis pekerjaan
4) Jarak dari rumah ke posyandu

(Andryana,2015: 12 ).

Menurut Sujanto (1996) dari Magdalena (2014) mengatakan bahwa minat dapat dipengaruhi oleh faktor :

1) Pengetahuan

2) Pengamatan

3) Tanggapan

4) Persepsi

5) Sikap

Komponen-komponen minat antara lain :

1) Dorongan

2) Keinginan

3) Kecenderungan

4) Ambisi

5) Kemauan

6) Harapan

\section{Konsep Ibu}

Ibu adalah perempuan yang sudah bersuami dan mempunyai anak dan merupakan panggilan pada kaum wanita yang patut untuk dihormati (Alwi Hasan, 2002: 122).

\section{Fungsi Ibu}

1) Asih adalah memberikan kasih sayang, perhatian, rasa aman kepada anggota keluarga sehingga memungkinkan anak tumbuh dan berkembang sesuai dengan usia kebutuhan.

2) Asuh adalah menuju kebutuhan pemeliharaan dan perawatan anak sehingga kesehatannya terpelihara.

3) Asah adalah memenuhi kebutuhan pendidikan anak sehingga siap menjadi manusia dewasa yang mandiri dalam mempersiapkan masa depan (Effendy, 1998: 36).

\section{Konsep Balita}

Secara harfiah, balita atau anak bawah lima tahun adalah anak usia kurang dari lima tahun sehingga bayi usia dibawah satu tahun juga termasuk dalam golongan ini. Namun, karena faal (kerja alat tubuh semestinya) bayi usia dibawah satu tahun berbeda dengan anak usia diatas satu tahun, banyak ilmuwan yang membedakannya. Anak usia 1-5 tahun dapat pula dikatakan mulai disapih 
atau selepas menyusu sampai dengan prasekolah. Sesuai dengan pertumbuhan badan dan perkembangan kecerdasannya, faal tubuhnya juga mengalami perkembangan sehingga jenis makanan dan cara pemberiannya pun harus disesuaikan dengan keadaannya (Proverawati, 2009:27)

Balita usia 1-5 tahun di kelompokkan menjadi 2, yaitu anak lebih dari usia 1-3 tahun dikenal dengan balita, dan usia lebih dari 3-5 tahun dikenal prasekolah. Anak dibawah lima tahun merupakan kelompok yang pertumbuhan menunjukkan pertumbuhan badannya yang pesat namun juga tersaring yang menderita kekurangan gizi (Proverawati, 2009:27).

Masa balita adalah periode perkembangan fisik dan mental yang pesat. Pada masa ini otak balita telah siap menghadapi berbagai stimulasiseperti berjalan dan berbicara lebih lancar. Perlunya perhatian lebih dalam tumbuh kembang di usia balita balita bahwa fakta kurangnya status gizi yang terjadi padamasa balita. Usia balita merupakan kelompok yang menunjukkan pertumbuhan badan yang pesat sehingga memerlukan zatzat gizi yang tinggi disetiap kilogram berat badannya. Berikut ini prinsip pemberian nutrisi pada balita:

1) Tinggi energi dan protein, vitamin dan mineral

2) Dapat diterima oleh anak dengan baik

3) Diproduksi oleh setempat dengan menggunakan bahan-bahan yang sehat

4) Disimpan dan praktis penggunaannya

5) Ringkas dan mempunyai nilai maksimal (Marmi, 2012:23)

\section{Konsep Taman Posyandu}

Menurut Dinkes Jatim (2013) taman posyandu adalah pengembangan posyandu purnama atau mandiri yang diberi tambahan layanan pengembangan anak usia dini (PAUD) dan bina keluarga balita (BKB).

Taman posyandu bukan suatu wadah atau organisasi yang baru, namun merupakan perluasan fungsi dan kegiatan posyandu purnama mandiri. Sehingga tidak perlu membentuk posyandu baru atau mengganti nama posyandu yang sudah ada, begitu juga dengan BKB dan PAUD yang sudah ada dan berkembang. Jadi akan disebut taman posyandu bila di suatu wilayah sudah ada posyandu, BKB dan PAUD yang beroperasi dengan baik dan rutin. Sehingga anak balita akan mendapatkan layanan secara menyeluruh yaitu kesehatannya di posyandu, rangsangan pendidikan di PAUD dan parenting (pengasuhan balita oleh orang tua) di BKB.

Pengelola dan Pelaksana Taman Posyandu

Menurut Dinkes Jatim (2013) pengelola Taman Posyandu adalah TP-PKK di semua jenjang. Di Provinsi adalah TP-PKK Provinsi, di Kabupaten atau Kota adalah TP-PKK Kabupaten atau Kota, di Kecamatan adalah TP-PKK Kecamatan dan di Desa adalah PKK Desa.

Pelaksana taman posyandu adalah kader yaitu bisa kader posyandu, BKB maupun kader PAUD yang sudah dilatih.

\section{Kegiatan Taman Posyandu}

1) Posyandu yang bertujuan untuk deteksi dini tumbuh kembang balita.

2) PAUD yang bertujuan untuk pembinaan anak sejak lahir sampai dengan usia 6 tahun yang dilakukan melalui pemberian rangsangan pendidikan untuk membantu pertumbuhan dan perkembangan jasmani dan rohani agar anak memiliki kesiapan dalam memasuki pendidikan lebih lanjut.

3) BKB yang bertujuan untuk meningkatkan pengetahuan dan ketrampilan orang tua dalam pembinaan tumbuh kembang anak umur 0-5 tahun.

Kegiatan di taman posyandu secara keseluruhan yaitu posyandu, PAUD dan BKB harus sudah menerapkan prinsip perlindungan bagi anak. Sebagai contoh: 1) kader di Taman Posyandu dalam kegiatannya tidak menimbulkan rasa takut pada anak, 2) anak tidak menangis saat ditimbang, 3) alat peraga yang digunakan aman bagi anak-anak (tidak beracun, tidak tajam), dan lain sebagainya. 
Untuk anak-anak dengan kondisi khusus (balita terlantar), pelayanan perlindungan sosial dan tumbuh kembangnya secara terbadu telah difasilitasi oleh dinas sosial melalui Program Kesejahteraan Sosial Anak (PKSA) yang dilaksanakan di Taman Anak Sejahtera (TAS).

Untuk meningkatkan sarana dan pelayanan di posyandu, para kader taman posyandu bisa bermitra dengan PNPM Pedesaa, PNPM Mandiri Pedesaan Generasi Sehat dan Cerdas yang ada di desa dengan upaya untuk:

1) Mengembangkan gedung posyandu, PAUD dan BKB

2) Memberikan makanan tambahan pada bayi dan balita

3) Sarana dan prasarana yang menunjang operasional posyandu.

\section{Tempat Pelaksanaan Taman Posyandu}

Taman posyandu bisa dilaksanakan dengan model pelayanan lengkap terintegrasi satu atap dengan pelayanan lengkap terintegrasi tidak satu atap. Dilaksanakan menetap di satu tempat di Rumah Warga, Balai RT/RW/Desa atau Rumah Posyandu (khusus untuk posyandu).

Tempat pelayanan PAUD dapat menggunakan fasilitas desa, fasilitas umum, sekolah atau bangunan yang tersedia dan memenuhi syarat sebagai berikut:

1) Bertempat di lokasi strategis

2) Kondisi bangunan cukup layak, aman dan nyaman bagi anak

3) Memiliki ruangan yang cukup untuk kegiatan

4) Memiliki halaman untuk bermain

5) Tersedia MCK yang dapat diakses oleh anak-anak/orang tua

6) Tersedia sanitasi air bersih

7) Penerangan dan ventilasi udara cukup

8) Bebas polusi dan suara bising

Pelaksanaan BKB bisa dilaksanakan bersama dengan posyandu, di rumah warga, balai RT/RW/Desa.

\section{Waktu Pelaksanaan Taman Posyandu}

Jadwal ditentukan sendiri oleh pelaksana dan masyarakat sesuai dengan kesepakatan, namun pengaturan jadwal layanan perlu dilakukan mengingat terbatasnya tempat dan jumlah kader yang ada. Secara umum pelaksana masing-masing layanan adalah sebagai berikut:

1) Pelayanan posyandu : 1 kali per bulan

2) Pelayanan BKB : 1-2 kali perbulan

3) Pelayanan POS PAUD : 3-6 kali perminggu

Karena pelaksanaan kegiatan tidak di satu atap maka pengaturan jadwal perlu dilakukan namun pada prinsipnya tidak ada perbedaan atau mengubah apa yang sudah berjalan. Pelayanan PAUD sebagai layanan yang memiliki frekuensi hari buka tertinggi perlu diselaraskan dengan hari buka.

Bila hari buka PAUD bersamaan dengan hari buka posyandu, maka pada hari tersebut anak tidak perlu datang ke Pos Paud namun wajib untuk datang ke posyandu, termasuk apabila kader PAUD merangkap kader posyandu, maka pada hari tersebut kader diharapkan melaksanakan kegiatan yang ada di posyandu. Bisa juga diatur anak datang ke posyandu dulu, setelah mendapatkan pelayanan anak tersebut datang ke pos Paud sepanjang memungkinkan.

\section{Pembiayaan Taman Posyandu}

Pembiayaan taman posyandu dapat berasal dari berbagai sumber, antara lain:

1) Swadaya masyarakat

2) Swasta atau dunia usaha

3) Pemerintah baik APBD Provinsi/APBD Kabupaten atau APB Desa

4) Sumber-sumber lain yang sah dan tidak mengikat

Pembiayaan yang selama ini sudah berjalan baik di masing-masing kegiatan seperti di Posyandu atau PAUD, tetap saja mengikuti yang sudah ada.

\section{Pembina Taman Posyandu}

Sebagai pembina pengelolaan dan pelaksanaan taman posyandu adalah SKPD terkait mulai di tingkat provinsi 
sampai jajarannya di tingkat kecamatan yaitu:

1) Dinas Pendidikan dan Kebudayaan

2) Dinas Kesehatan

3) $\mathrm{BKKBN}$

4) Badan Pemberdayaan Masyarakat

5) Badan Pemberdayaan Perempuan dan $\mathrm{KB}$

\section{6) Biro Kesra}

\section{Pelaporan}

Laporan disesuaikan dengan format yang sudah ada masing-masing di kantor dinas terkait, sedangkan laporan taman posyandu dikirim ke Sektap Taman Posyandu.

\section{METODE PENELITIAN}

Jenis penelitian ini adalah kuantitatif dengan pendekatan koresional yaitu penelitian yang bertujuan untuk menemukan ada tidaknya hubungan antar variabel dalam suatu populasi (Sugiyono, $2011: 5$ ).

Penelitian ini menganalisis tentang hubungan pengetahuan Ibu balita dengan minat Ibu balita tentang taman posyandu di posyandu pos 3 Cokromenggalan Kelurahan Cokromenggalan Kecamatan Ponorogo Kabupaten Ponorogo.

Dalam penelitian ini menggunakan bentuk "cross sectional" yaitu jenis penelitian yang menekankan pada waktu pengukuran atau observasi data variabel independen dan dependen hanya satu kali pada satu saat (Notoatmodjo, $2010: 37$ ).

Penelitian ini di Posyandu pos 3 Cokromenggalan Kelurahan Cokromengalan Kecamatan Ponorogo Kabupaten Ponorogo, dan waktu penelitian bulan Januari 2017.

Dalam penelitian ini yang menjadi populasi adalah semua ibu balita yang berjumlah 52 responden di Pos 3 Taman Posyandu Cokromenggalan Kelurahan Cokromenggalan Kecamatan Ponorogo Kabupaten Ponorogo pada bulan Januari 2017. Sampel dalam penelitian ini adalah semua ibu balita yang datang di Pos 3 Taman Posyandu Cokromenggalan. Jumlah sampel dalam penelitian ini adalah 30 orang pada bulan Januari 2017.

Teknik sampling penelitian ini menggunakan teknik Accidental sampling dilakukan berdasarkan kebetulan. Siapa saja yang ditemui asalkan sesuai dengan persyaratan data yang diinginkan. (Notoatmodjo, $2010: 125$ )

Dalam penelitian ini yang menjadi variabel bebas adalah pengetahuan Ibu balita tentang taman posyandu. variabel dependen adalah minat ibu balita tentang taman posyandu.

Instrumen yang digunakan pada penelitian ini adalah kuesioner dengan pilihan ganda untuk variabel pengetahuan dan angket pernyataan untuk variabel minat.

Untuk mengetahui hubungan pengetahuan Ibu balita dengan minat Ibu balita tentang taman posyandu digunakan uji korelasi, uji korelasi yang dipakai dalam penelitian ini adalah "Spearman Rank" dengan bantuan SPSS 18,0 for windows dengan taraf signifikasi $\mathrm{p}<0,05$ Ho ditolak dan HI diterima, jadi ada hubungan antara 2 variabel.

\section{HASIL PENELITIAN DAN} PEMBAHASAN

1. Pengetahuan

Tabel 1

Distribusi Frekuensi Pengetahuan Ibu Balita.

\begin{tabular}{llcl}
\hline No & Pengetahuan & Frekuensi & $\%$ \\
\hline 1 & Baik & 5 & 16,7 \\
\hline 2 & Cukup & 10 & 33,3 \\
\hline 3 & Kurang & 15 & 50 \\
\hline & Total & 30 & 100 \\
\hline
\end{tabular}

Sumber: data primer penelitian 2017

Berdasarkan tabel 1 di atas dapat dilihat bahwa setengahnya responden yang mempunyai pengetahuan kurang sebanyak 15 responden (50\%), hampir setengahnya responden yang mempunyai pengetahuan cukup sebanyak 10 responden $(33,3 \%)$ dan sebagian kecil responden yang mempunyai pengetahuan baik sebanyak 5 responden (16,7\%).

Pengetahuan adalah hasil tahu dan ini terjadi apabila seseorang melakukan penginderaan terhadap suatu obyek tertentu. Penginderaan terjadi melalui panca indera manusia, yakni indera penglihatan, pendengaran, penciuman, perasa dan peraba. 
Sebagian besar pengetahuan manusia diperoleh melalui mata dan telinga. Menjelaskan bahwa pengetahuan mencakup domain kognitif enam tingkat yaitu tahu (know), memahami (comprehension), aplikasi (application), analisis (analysis), sintesis (syntesis) dan evaluasi (evaluation).

Menurut Wawan (2011:16) pengetahuan dipengaruhi oleh 2 faktor yaitu faktor internal dan faktor eksternal. Faktor internal meliputi: usia, intelegensia dan pemahaman, pendidikan, pekerjaan. Dan faktor eksternal, meliputi: dukungan keluarga atau social, sarana informasi, lingkungan, dan social budaya

Sesuai pendapat Wawan (2011:16) semakin bertambah usia, semakin banyak pula pengalaman dan pengetahuan yang dimilikinnya. dimana semakin dewasa seseorang maka pola pikirannya akan semakin berkembang dan kemungkinan penerimaan informasi akan lebih baik.

Semakin tinggi latar pendidikan seseorang, maka semakin mudah menerima informasi sehingga makin banyak pula pengetahuan yang dimiliki. Sebaliknya pendidikan kurang akan menghambat pola pengetahuan yang dimiliki seseorang. (Wawan, 2011:16).

Berdasarkan hasil penelitian diatas dapat ditarik kesimpulan, bahwa kurangnya pengetahuan responden disebabkan karena beberapa faktor, khususnya faktor usia, dan pendidikan. Banyaknya pengetahuan yang kurang pada ibu tersebut didukung karena tingkat pendidikan dari responden yang sebagian besar memiliki tingkat pendidikan hanya sampai tingkat dasar saja, karena semakin tinggi pendidikan seseorang maka akan mudah menerima informasi sehingga semakin banyak pula pengetahuan yang dimiliki. Sebaliknya pendidikan yang kurang akan menghambat perkembangan penyerapan informasi dan semakin sedikit pula pengetahuan yang dimiliki seseorang.

2. Minat

Tabel 2

Distribusi Frekuensi Minat Ibu Balita Tentang Taman Posyandu

\begin{tabular}{llcc}
\hline No & Minat & Frekuensi & Prosentase \\
\hline 1 & Positif & 14 & 46,7 \\
\hline 2 & Negatif & 16 & 53,3 \\
\hline & Total & 30 & $100 \%$ \\
\hline
\end{tabular}

Sumber: data primer penelitian 2017

Berdasarkan tabel 2 dapat dilihat bahwa sebagian besar responden yang memiliki minat negatif sebanyak 16 responden (53,3\%). Dan hampir setengahnya responden yang memiliki minat positif sebanyak 14 responden $(46,7 \%)$.

Menurut Andryana (2015: 12) mengatakan bahwa minat dapat dipengaruhi faktor umur responden, tingkat pendidikan, jenis pekerjaan, dan jarak dari rumah ke posyandu. Semakin tinggi dan semakin formal tingkat pendidikan yang dimiliki seseorang maka semakin besar pula kegiatan yang bersifat intelek yang dilakukan. L.W. Green mengatakan bahwa "jika ada seseorang yang mempunyai pengetahuan baik, maka ia mencari pelayanan yang lebih kompeten atau lebih aman baginya".

Berdasarkan hasil penelitian diatas dapat ditarik kesimpulan, bahwa orang yang mempunyai pendidikan rendah akan memberikan minat yang negatif dibandingkan mereka yang berpendidikan lebih tinggi. Solusi terhadap masalah diatas, pemberian informasi untuk Ibu balita yang minatnya negatif agar rutin mengikuti taman posyandu, dan untuk ibu balita yang minatnya positif selalu diberi motivasi untuk tetap rutin mengikuti kegiatan taman posyandu.

3. Hubungan Pengetahuan Ibu Balita Dengan Minat Ibu Balita Tentang Taman Posyandu Di Posyandu Pos 3 Cokromenggalan Kelurahan Cokromenggalan Kecamatan Ponorogo Kabupaten Ponorogo 
Tabel 3

Hasil Uji Statistik Spearman Rank

\begin{tabular}{|c|c|c|c|c|}
\hline & & & Pengetahuan & Minat \\
\hline \multirow[t]{6}{*}{$\begin{array}{l}\text { Spearman' } \\
\text { Rho }\end{array}$} & $\begin{array}{l}\text { s Penge- } \\
\text { tahuan }\end{array}$ & $\begin{array}{l}\text { Correlation } \\
\text { Coefficient }\end{array}$ & 1.000 & .803 \\
\hline & & Sig. (2-tailed) & . & .000 \\
\hline & & $\mathrm{N}$ & 30 & 30 \\
\hline & Minat & $\begin{array}{l}\text { Correlation } \\
\text { Coefficient }\end{array}$ & .803 & 1.000 \\
\hline & & Sig. (2-tailed) & .000 & . \\
\hline & & $\mathrm{N}$ & 30 & 30 \\
\hline
\end{tabular}

Berdasarkan hasil perhitungan menggunakan uji statistik Spearman Rank dengan bantuan SPSS 18.0 For Windows pada taraf signifikasi $\rho<0,05$ Ho ditolak dan HI diterima dan diperoleh hasil $\rho=0,000$ $<0,05$ yang berarti (signifikan) sehingga $\mathrm{Ha}$ diterima dengan nilai koefesiensi korelasi 0.803 yang berarti ada hubungan pengetahuan ibu balita dengan minat ibu balita tentang taman posyandu di posyandu pos 3 Cokromenggalan kelurahan Cokromenggalan kecamatan Ponorogo kabupaten Ponorogo dengan tingkat hubungan sangat kuat.

Hasil penelitian ini sesuai dengan hasil penelitian yang dilakukan oleh Lutfia Ulfa Ardihansam (2013) tentang minat ibu balita terhadap taman posyandu di Desa Tanjungsari, Kecamatan Boyolangu, Kabupaten Tulungagung. Variabel yang digunakan variabel tunggal yaitu minat ibu balita terhadap Taman Posyandu di Desa Tanjungsari Kecamatan Boyolangu Kabupaten Tulungagung sebanyak 11 orang. Penelitian ini dalam karya tulis ilmiah program studi diploma III kebidanan Akademi Kebidanan Dharma Husada Kediri dengan menggunakan metode penelitian deskriptif. Sampel yang digunakan adalah total sampling, instrumen yang digunakan adalah kuesioner. Dari hasil penelitian yang dilakukan di dapat hasil sebagai berikut :

Minat ibu balita tentang penilaian terhadap taman posyandu di Desa Tanjungsari Kecamatan Boyolangu Kabupaten Tulungagung yang mempunyai minat positif sebanyak 5 responden $(45,45 \%)$, sedangkan yang mempunyai minat negative sebanyak 6 responden $(54,54 \%)$. Ibu balita di Desa Tanjungsari yang mempunyai minat negatif didapatkan dari responden yang pendidikannya dasar (SD, MI, SMP, MTS). Pada umumnya tingkat pengetahuan ibu balita yang rendah diduga sebagai salah satu faktor kinerja yang secara tidak langsung menyebabkan minat kunjungan ibu di taman posyandu berkurang.

Berdasarkan hasil penelitian diatas dapat ditarik kesimpulan bahwa terdapat hubungan pengetahuan Ibu balita tentang taman posyandu dengan minat Ibu balita tentang taman posyandu. Dengan pengetahuan Ibu yang kurang tentang taman posyandu tersebut menyebabkan minat Ibu tentang taman posyandu rendah. Oleh karena itu, sebagai upaya untuk meningkatkan pengetahuan dan minat kunjungan ibu terhadap taman posyandu tenaga kesehatan hendaknya lebih meningkatkan mutu pelayanan dan memberikan penyuluhan tentang Taman Posyandu agar minat positif ibu balita tentang Taman Posyandu semakin baik dan pengetahuan ibu balita tentang taman posyandu bertambah.

\section{KESIMPULAN}

Berdasarkan hasil penelitian dan pembahasan, dapat ditarik kesimpulan bahwa:

1. Pengetahuan ibu balita tentang taman posyandu di posyandu pos 3 Cokromenggalan Kelurahan Cokromenggalan Kecamatan Ponorogo Kabupaten Ponorogo setengahnya sebanyak 15 responden (50\%) berpengetahuan Kurang.

2. Minat ibu balita tentang taman posyandu di posyandu pos 3 Cokromenggalan Kelurahan Cokromenggalan Kecamatan Ponorogo Kabupaten Ponorogo sebagian besar sebanyak 16 responden $(53,3 \%)$ memiliki minat negatif.

3. Ada hubungan pengetahuan Ibu balita dengan minat Ibu balita tentang taman posyandu di posyandu pos 3 Cokromenggalan Kelurahan 
Cokromenggalan Kecamatan Ponorogo Kabupaten Ponorogo dengan nilai $\rho$ 0,000 dengan coeffisien correlation 0,803 dengan tingkat hubungan sangat kuat.

\section{SARAN}

1. Bagi Institusi Pendidikan

Institusi pendidikan diharapkan agar lebih meningkatkan kualitas pendidikan, sehingga terbentuk tenaga professional dalam memberikan pelayanan kepada masyarakat nantinnya.

2. Bagi Tenaga Kesehatan

Diharapkan dapat meningkatkan peran dan fungsi pelayanan bagi masyarakat dalam memberikan informasi kesehatan khususnya tentang pemanfaatan taman posyandu.

3. Bagi Tempat Penelitian

Diharapkan pada bidan dan kader-kader Taman Posyandu dapat memberikan penjelasan dan informasi tentang manfaat mengikuti Taman Posyandu kepada ibu balita.

4. Bagi Ibu Balita

Diharapkan ibu balita menambah wawasan tentang taman posyandu melalui sumber terpercaya, misalnya petugas kesehatan (bidan, dokter), atau melalui media masa seperti media sosial, surat kabar, televisi, maupun buku-buku yang berkaitan dengan taman posyandu.

\section{DAFTAR PUSTAKA}

Ardhiansam, Lutfia Ulfa. 2013. Minat Ibu Balita Terhadap Taman Posyandu di Desa Tanjungan Kecamatan Boyolangu Kabupaten Tulungagung. Skripsi tidak diterbitkan. Tulungagung : Program Studi D III Kebidanan. AKBID Dharma Husada Kediri.

Arikunto, Suharsimi. 2010. Prosedur Penelitian Suatu Pendekatan Praktik. Jakarta: Rineka Cipta

Azwar, Saifuddin. 2011. Sikap Manusia Teori dan Pengukuranya. Yogyakarta: Pustaka Pelajar.

Dinkes Ponorogo. 2014. Profil Kesehatan Ponorogo, (online PDF), (http://www.depkes.go.id, diakses 1 November 2016).
Dinkes Jatim. 2014. Profil Kesehatan Provinsi jawa Timur. (online PDF), (http://dinkes.JatimProv.go.id, diakses 27 November 2016).

Dinkes Jatim. 2014. Petunjuk Teknis Taman Posyandu

Effendi, Nasrul. 1998. Dasar-Dasar Keperawatan Kesehatan Masyarakat. E/2. Jakarta. EGC 1998

Idris, Nahri. \&Afriani, H. 2009. Minat Peternak Untuk Mengembangkan Ternak Sapi Kawasan Perkebunan Kelapa Sawit. Jurnal Penelitian Universitas Jambi Seri Humaniora, (Online), Vol. 11, No. 2, Hal. 0107,(http://onlinejournal.unja.ac.id/in dex.php/humaniora/article/downloa d/1917/1, diakses 6 Desember 2016).

Ismawati, Cahyo. S. 2010. Posyandu dan Desa Siaga. Yogyakarta: Nuha Medika

Kemenkes RI. 2014. Profil Kesehatan Indonesia. (Online PDF). (http://www.kemkes.go.id, diakses 26 November 2016).

Marmi, 2012. Asuhan Neonatus, Bayi, Balita dan Anak Prasekolah. Yogyakarta: Pustaka Pelajar

Notoatmodjo, Soekidjo. 2010. Metodologi Penelitian Kesehatan. Jakarta: Rineka Cipta

Nursalam. 2011. Konsep dan Penerapan Metodologi Penelitian Ilmu Keperawatan. Jakarta: Salemba Medika

Profil Desa dan Kelurahan Cokromenggalan Kecamatan Ponorogo Kabupaten Ponorogo 2015

Sugiyono. 2011. Metodologi Penelitian Kuantitatif, Kualitatif. Bandung: ALFABETA,W

Slameto. 2010. Belajar dan Faktor-faktor yang Mempengaruhi. Jakarta: Rineka Cipta

Suharso\& Ana Retroningsih. 2005. Kamus Besar Bahasa Indonesia. Semarang: Pera Widya Karya 
Triwibowo , Cecep dan Mitha Erlisya. 2015. Pengantar Dasar Ilmu Kesehatan Masyarakat. Yogyakarta: Nuha Medika

Proverawati, Atikah. 2009. Gizi untuk Kebidanan. Yogyakarta: Nuha Medika

Referensi Kesehatan. 2010. Konsep minat. (Online),(http://creasoft.wordpress.com/20 10/03/18/konsep-minat, diakses 12 Januari 2017)

Ria Andryana. 2015. Minat Ibu Mengunjungi Posyandu di Wilayah Kerja Puskesmas Simpang Baru Kecamatan Tampan. Jom FISIP, (Online), Vol 2, No.2,(http://) 